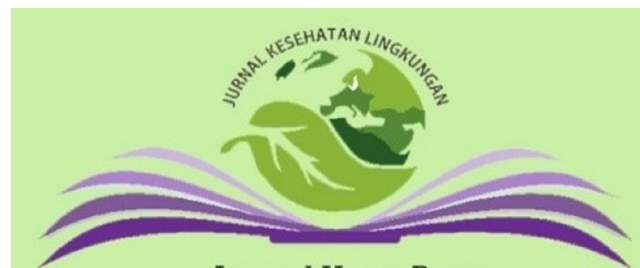

Journal Home Page:

https://e-journal.unair.ac.id/JKL

\section{Jurnal Kesehatan Lingkungan}

Vol. 14 No. 1

DOI: $10.20473 / j$ lkl.vl4il.2022.37-44

ISSN: 1829 - 7285

E-ISSN: 2040 - 881X

\title{
DETERMINANT FACTORS OF STUNTING IN WEST PASAMAN DISTRICT, WEST SUMATERA INDONESIA
}

Sari Arlinda ${ }^{1 *}$, Muchsin Riviwanto ${ }^{1}$, Burhan Muslim ${ }^{1}$, Awalia Gusti ${ }^{1}$, Defriyani Dwi Yanti

${ }^{1}$ Department of Environmental Health, Health Polytechnic of the Ministry of Health Padang, 25146, Indonesia

${ }^{2}$ Department of Nutrition, Health Polytechnic of the Ministry of Health Padang, 25146, Indonesia

Corresponding Author:

*) sariarlinda29@gmail.com

\section{Article Info}

Submitted

In reviewed

Accepted

Available Online

31 January 2022

Keywords : Toddler, Stunting, Infectious Diseases, nutrition, Environment

Published by Fakultas Kesehatan Masyarakat Universitas Airlangga

\begin{abstract}
Introduction: The age group that is susceptible to disease and must get balanced nutrition to avoid stunting is the age group of infants under five years old (toddlers). Toddlers with stunting are caused by many factors, including parenting patterns, health services that can be reached by toddlers, environmental conditions where toddlers live, food consumption as food security for toddlers. The purpose of this research was to know the determinants of stunting in The West Pasaman Regency. Methods: The design of this study was a cross-sectional survey by interviewing 1,156 respondents in West Pasaman Regency which were selected using a simple randomized method. A structured questionnaire that has passed validity and reliability tests was used to collect data. Generalized Structural Equation Modeling was used to determine these determinants. Results and Discussion: The study showed that 30.8\% of children under five years old in West Pasaman were stunted with the disease being diarrhea, which was $18.8 \%$. Most of the children under five live in families with a low socioeconomic level, namely $53.9 \%$, with a low education of $58.2 \%$. The results of the re-specification of the model show that the variable that has the greatest indirect influence on the incidence of stunting is the diet variable (path coefficient $=0.90$ ) compared to parenting and environment. Conclusion: Infectious diseases are a direct cause of stunting in toddlers. Parenting behavior factors, eating behavior factors, and environmental factors are indirect causes, but these factors play a very important role in causing stunting in toddlers. Preventive activities are needed, such as counseling for child growth and development, formation of caring for neighbors, a social gathering for nutritious food and pre-marital counseling which discusses parenting, eating patterns, and a sanitary environment.
\end{abstract}

\section{INTRODUCTION}

One of the health problems that is still a global problem is the incidence of stunting in children under five. In 2017, it is known that approximately 150 million children under five are stunted, or about $22.2 \%$ of all children under five in the world. Most of the children under five who experienced stunting came from Asia (55\%). The number of children under five who are stunted in Asia is 83.6 million, and the highest cases are from South Asia with a proportion of $58.7 \%$ and the lowest cases are from Central Asia with a proportion of $0.9 \%$. Based on data collected by the World Health Organization (WHO), it is found that the incidence of stunting in children under five in Indonesia in 2005-2017 was with an average prevalence of $36.4 \%$. Data quoted from the South East Asia Regional (SEAR) states that the prevalence of stunting under five in Indonesia ranks third from the Southeast Asian region (1-2). In 2017, in Indonesia there were cases of very short toddlers by $9.8 \%$ and cases of short toddlers in Indonesia by
$19.8 \%$. Judging from the previous year, this number has increased, as previously the cases of very short toddlers by $8.5 \%$ and short toddlers by $19 \%$ (2). Stunting disease is a nutritional status problem experienced by infants under five years old for a long period and this can be seen with shorter body postures compared to their peers (2-4). Moreover, slow motor development and low intelligence levels are also related with stunting in toddlers. Toddlers with stunting have lower abilities in locomotor, eye and hand alignment, hearing and speaking levels, or other abilities when compared to children under five with normal growth. In adulthood, it causes loss of productivity due to low cognitive levels and impaired growth. Toddlers with stunting have more susceptibility to disease and in adulthood, they are at risk for degenerative diseases such as obesity (overweight), diabetes, coronary heart disease, hypertension, osteoporosis, decreased performance, and productivity. Birth weight and blood pressure in infancy also have a negative relationship with blood pressure in adulthood (4). 
Factors that can influence the incidence of stunting include the level of parental education, parental occupation and income level, parenting patterns, history of exclusive breastfeeding, and histories of infectious diseases, such as diarrheal diseases and acute respiratory infections (ARI). Exclusive breastfeeding can reduce the child's risk for stunting, as seen from the number of stunting cases found in children who are not exclusively breastfed compared to children who are exclusively breastfed. Stunting in children is caused by growth disorders. In addition, children who often experience infections will easily experience nutritional deficiencies. If a toddler has an infection with a long and frequent duration, the child will be more prone to stunting (5). Several risk factors that cause stunting in infants under five years old include socio-economic aspects, parental height, history of pregnancy disease, birth weight of toddlers, and history of infectious diseases of toddlers (6). Based on WHO, the factors that influence the incidence of stunting are coverage factors related to the quality of health services, parenting, environmental and food security factors, family factors, inadequate complementary food factors, breastfeeding factors, and infectious disease factors (1). A recent study on the Government of India revealed that environmental sanitation programs affect the reduction of infant mortality. This program is proven to increase the average height of toddlers and children in India. The sanitation program carried out by the Government of India is called as Total Sanitation Champaign. This activity focused on improving sanitation in rural India. The results of the program revealed that there was a difference in the height growth of children between recipients of motivation and subsidized latrines than children in control villages. Children who are motivated and receive subsidized latrines experience higher growth than children who are not motivated and do not receive subsidized latrines. Based on the results of the program of Total Sanitation Champaign, we need to improve the provision of access to clean water and latrines, as well as needs of personal hygiene for women (7).

The interaction between genetic and environmental factors is an important aspect of human growth. The fertilization phase produces a genetic blueprint that is needed by humans to determine their physical body shape. However, this achievement is strongly influenced by the environment, where an environment that has a negative influence will make it difficult to achieve genetic potential, resulting in stunting
(8). Sanitation facilities that are used and meet the requirements are households that can reach sanitation facilities equipped with closet, septic tanks, and sewers. Also, the facilities for storing and processing feces are used individually or communally. In 2017 in Indonesia, the percentage of households that had easy access to proper sanitation facilities was $67.89 \%$ (5).

West Sumatra is a province that has the affordability of adequate drinking water sources and the affordability of proper sanitation facilities below the Indonesian average of $68.83 \%$ and $52.77 \%$, which is the sixth-lowest (2). One of the districts with the lowest access to drinking water and proper sanitation is West Pasaman, with $65.4 \%$ of households having access to a latrine, and $58.7 \%$ of households having access to drinking water (9). The prevalence of stunting under five in West Sumatra is around 35\% with the highest district being West Pasaman Regency at $34.2 \%$ spread over 10 villages. Therefore, it is necessary to analyze the determinants of stunting in stunted toddlers in The West Pasaman Regency.

\section{METHODS}

This research was conducted by observing the sample once at the same time (cross-sectional study). Data collection was carried out through observation, interviews, and measuring the symptoms of the subject. Factor and effect measurements were carried out at the same time. The data collected were analyzed by statistical testing to determine the effect of the determinants on stunting cases.

In this study, the population was obtained from all families with toddlers in 6 sub-districts and 12 Nagari in West Pasaman Regency. The selected sample was interviewed with 1,156 respondents from 6 sub-districts and 12 Nagari in West Pasaman Regency. The selection of these six sub-districts was based on data showing that the number of stunting cases was high in the area. The sample selection was based on a simple random method where the sample was randomly selected. The data was obtained by using a questionnaire that has been tested (validity and reliability). The endogenous variables observed were stunting in toddlers, exogenous latent variables were parenting, diet, and environment, and endogenous latent variables were infectious diseases.

Generalized Structural Equation Modeling (GSEM) is a multivariate analysis that is used to look at variables directly or indirectly on the overall determinant factors that influence the incidence of stunting. 


\section{RESULTS}

Univariate data processing is data processing carried out to display the frequency distribution of each research variable. Based on table 1 describing the characteristics of respondents, the results of the education of respondents are generally high school education equivalent $(60.3 \%)$, aged $>30$ years $(60.3 \%)$, household work / not working (76.8\%), and most of them have toddlers with the female gender.

Table 1. Characteristics of Respondents

\begin{tabular}{lcc}
\hline \multicolumn{1}{c}{ Criteria } & Mother (\%) & Father (\%) \\
\hline Education & & \\
No schooling & 0.7 & 4.1 \\
Elementery School & 12.2 & 33.7 \\
Junior High School & 26.8 & 25.1 \\
Senior High School & 60.3 & 29.0 \\
University & 0.7 & 7.1 \\
\hline Age & & \\
15-19 & 0.7 & 0.8 \\
$20-24$ & 12.2 & 4.6 \\
25-29 & 26.8 & 16.6 \\
>=30 & 60.3 & 78.0 \\
\hline Profession & & \\
Does not work & 76.8 & 3.0 \\
Farmer & 8.7 & 43.7 \\
Civil servants & 3.7 & 2.1 \\
TNI/Polri & 0.3 & 0.7 \\
Entrepreneur & 6.0 & 29.1 \\
Private Employees & 4.1 & 11.0 \\
Fisherman & - & 7.9 \\
\hline Balita & & \\
Boy & 49.0 & 1.8 \\
Girl & 51.0 & \\
\hline
\end{tabular}

Table 2 shows that the 1,156 respondents studied were $30.8 \%$ stunted children in West Pasaman. The distribution of diarrheal disease in children in West Pasaman is $18.8 \%$, dysentery is $1.1 \%$, and worms infection is $1.1 \%$.

Table 2. Incidence of Stunting and Infectious Diseases

\begin{tabular}{ccc}
\hline $\begin{array}{c}\text { Stunting and } \\
\text { Infectious Disease }\end{array}$ & $\mathbf{f}$ & $\mathbf{\%}$ \\
\hline Stunting & 800 & \\
No & 356 & 69.2 \\
Yes & $\mathbf{1 , 1 5 6}$ & 30.8 \\
Total & & $\mathbf{1 0 0}$ \\
\hline Diarrhea & 939 & \\
No & 217 & 81.2 \\
Yes & $\mathbf{1 , 1 5 6}$ & 18.8 \\
Total & 1143 & $\mathbf{1 0 0}$ \\
\hline Worms & 13 & \\
No & $\mathbf{1 , 1 5 6}$ & 98.9 \\
Yes & & 1.1 \\
Total & 1,143 & \\
\hline Dysentery & 13 & 98.9 \\
No & $\mathbf{1 0 0}$ \\
Yes & & 1.1 \\
Total & $\mathbf{1 0 0}$ \\
\hline
\end{tabular}

Table 3. Based on the UNICEF theory, it states that Parenting is a contributing factor in the incidence of stunting. It is known that $62.2 \%$ of respondents are at risk age with categories below 19 years and above 30 years. $56.3 \%$ of mothers do not wash their hands with soap especially when feeding their children, $24.4 \%$ of mothers did not take their children to health services when their children were sick, $82 \%$ of their children's families smoke, $53.9 \%$ of them have low socioeconomic status, and $58.2 \%$ of mothers had low education.

Table 3. Frequency Distribution of Parenting Indicators

\begin{tabular}{|c|c|c|}
\hline Pola Asuh & f & $\%$ \\
\hline \multicolumn{3}{|l|}{ Mother's age } \\
\hline Risky & 719 & 62.2 \\
\hline No Risk & 437 & 37.8 \\
\hline Total & 1,156 & 100 \\
\hline \multicolumn{3}{|l|}{ Wash Hands With Soap } \\
\hline Yes & 651 & 56.3 \\
\hline No & 505 & 43.7 \\
\hline Total & 1,156 & 100 \\
\hline \multicolumn{3}{|c|}{$\begin{array}{l}\text { Sick Child was Brought To Health } \\
\text { Service }\end{array}$} \\
\hline Yes & 282 & 24.4 \\
\hline No & 874 & 75.6 \\
\hline Total & 1,156 & 100 \\
\hline \multicolumn{3}{|l|}{ Smoking } \\
\hline Yes & 948 & 82 \\
\hline No & 208 & 18 \\
\hline Total & 1,156 & 100 \\
\hline \multicolumn{3}{|l|}{ Socioeconomic Level } \\
\hline Low & 623 & 53.9 \\
\hline Middle & 420 & 36.3 \\
\hline High & 113 & 9.8 \\
\hline Total & 1,156 & 100 \\
\hline \multicolumn{3}{|l|}{ Mother's Education } \\
\hline Low & 673 & 58.2 \\
\hline High & 483 & 41.8 \\
\hline Total & 1,156 & 100 \\
\hline
\end{tabular}

Table 4. It is known that $35.9 \%$ of mothers do not give colostrum to their children at birth, $54.6 \%$ of mothers do exclusive breastfeeding, and $49.7 \%$ of mothers give complementary foods during breast milk for their children.

Table 4. Frequency Distribution of Dietary Indicators

\begin{tabular}{lcc}
\hline \multicolumn{1}{c}{ Dietary Habit } & $\mathbf{f}$ & $\mathbf{\%}$ \\
\hline Giving Colostrum & & \\
No & 415 & 35.9 \\
Yes & 741 & 64.1 \\
Total & $\mathbf{1 , 1 5 6}$ & $\mathbf{1 0 0}$ \\
\hline Exclusive Breastfeeding & & \\
Never & 215 & 18.6 \\
Sometimes & 118 & 10.2 \\
Often & 192 & 16.6 \\
Always & 631 & 54.6 \\
Total & $\mathbf{1 , 1 5 6}$ & $\mathbf{1 0 0}$ \\
\hline
\end{tabular}




\begin{tabular}{lcc}
\hline \multicolumn{1}{c}{ Dietary Habit } & f & \% \\
\hline Supplementary Feeding & & \\
Never & 170 & 14.7 \\
Sometimes & 133 & 11.5 \\
Often & 278 & 24.0 \\
Always & 575 & 49.7 \\
Total & $\mathbf{1 , 1 5 6}$ & $\mathbf{1 0 0}$ \\
\hline
\end{tabular}

Table 5. It is known that $77.9 \%$ of mothers have sufficient availability of clean water, $59.9 \%$ of mothers have healthy latrines for their families, $62.8 \%$ of mothers have good wastewater treatment, and $22.4 \%$ of mothers do manage good household waste.

Table 5. Frequency Distribution of Environmental Factor Indicators

\begin{tabular}{lcc}
\hline \multicolumn{1}{c}{ Environmental Factor } & $\mathbf{f}$ & $\mathbf{\%}$ \\
\hline Availability of Clean Water & & \\
$\quad$ Not Enough & 256 & 22.1 \\
Enough & 900 & 77.9 \\
$\quad$ Total & $\mathbf{1 , 1 5 6}$ & $\mathbf{1 0 0}$ \\
\hline Availability of Healthy Latrines & & \\
No & 463 & 40.1 \\
Yes & 693 & 59.9 \\
Total & $\mathbf{1 , 1 5 6}$ & $\mathbf{1 0 0}$ \\
\hline Water Waste Management & \\
Bad & 430 & 37.2 \\
Good & 726 & 62.8 \\
Total & $\mathbf{1 , 1 5 6}$ & $\mathbf{1 0 0}$ \\
\hline Waste Management & \\
Bad & 897 & 77.6 \\
Good & 259 & 22.4 \\
Total & $\mathbf{1 , 1 5 6}$ & $\mathbf{1 0 0}$ \\
\hline
\end{tabular}

Figure 1. Generalized Structural Equation Modeling (GSEM) analysis consists of exogenous endogenous latent variables and observed endogenous variables with the total of 18 variables. It is known that the results of the particular of the model indicate that the variable that has the greatest indirect influence on the incidence of stunting is the dietary variable (path coefficient $=0.90$ ) compared to parenting and environment.

The structural model produced in this study is stunting cases of 0.24 from infectious disease cases in infectious toddlers, and infectious diseases in toddlers 0.13 from parenting plus 0.90 from diet plus 0.09 from environmental factors.

Table 6. Based on calculation of the direct and indirect effects of latent variables from the stunting model above, it is known that the model contains one direct effect, namely infection. In addition, the model also contains three indirect effects, where parenting, diet, and the environment can pass through infection to see its relationship with stunting.

Table 6. Calculation of Direct Effect, Indirect Effect and Total Effect

\begin{tabular}{lccc}
\hline Latent Variable & $\begin{array}{c}\text { Direct } \\
\text { Effect }\end{array}$ & $\begin{array}{c}\text { Inderect } \\
\text { Effect }\end{array}$ & $\begin{array}{c}\text { Total } \\
\text { Effect }\end{array}$ \\
\hline Parenting & - & 0.13 & 0.13 \\
Dietary Habit & - & 0.9 & 0.9 \\
Environment & - & 0.09 & 0.09 \\
Infection & 0.24 & - & 0.24 \\
\hline
\end{tabular}

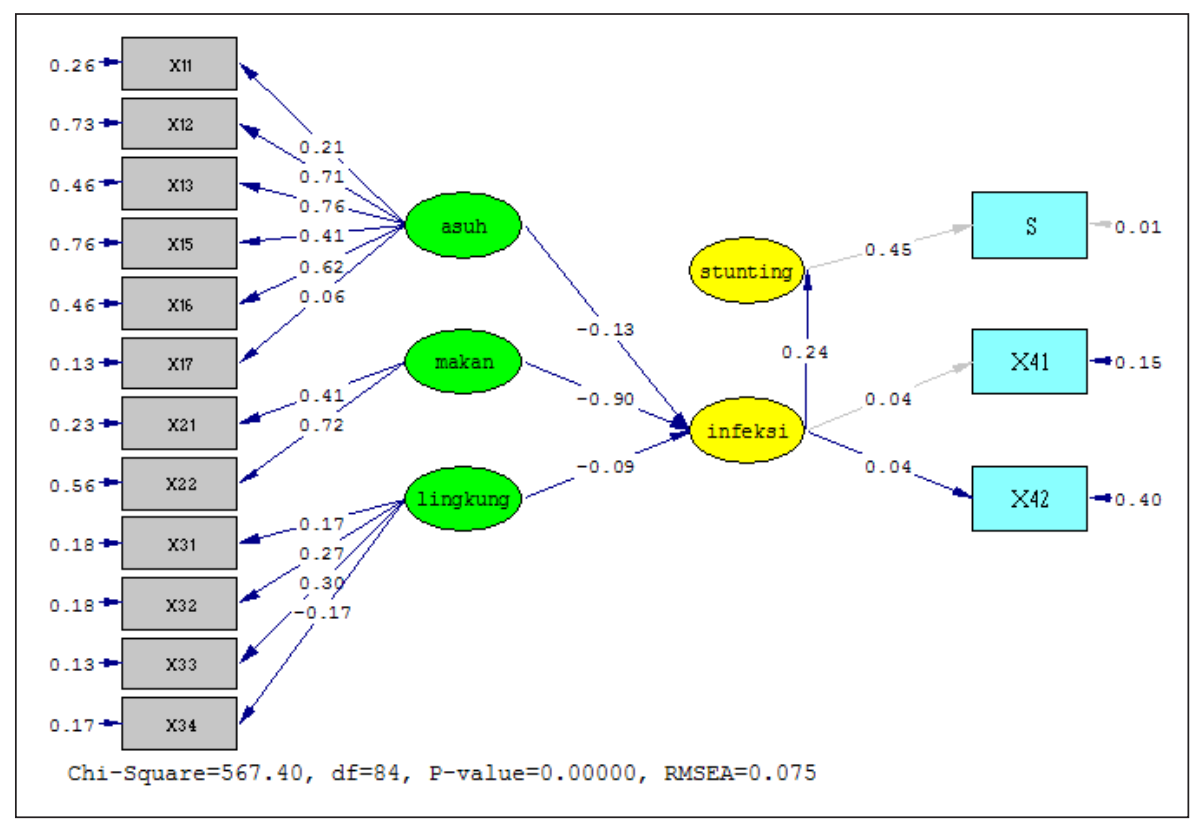

Figure 1. Stunting Model Respecific

\section{DISCUSSION}

Based on the results of the study, it is known that $30.8 \%$ of children stunted in West Pasaman, this figure is still the highest in West Sumatra. This is due to upbringing, infectious diseases and diet. The chronic condition of poor linear growth stems from the accumulation of poor nutrition and health conditions before and after the birth of a child causes stunting. The incidence of stunting 
increased at the age of 12 weeks. Then, when children were 3 years old, stunting cases were rare. Then, the toddler's height is also on the standard curve even though it is below it. Based on the child's age group, there were two periods of interpretation of stunting. The low height curve based on age (TB/U) in children aged 2-3 years may indicate a slow growth process so that they experience stunting. Meanwhile, in children who are more than 3 years old, this height abnormality means that their body condition has impaired growth or has stunted (10).

Several factors that cause stunting in children include low birth weight babies, inappropriate parenting and stimulation, frequent infections, lack of balanced nutritional intake, and other factors such as the environment that can cause stunting in children. A person cannot achieve growth determined by his genetic makeup if he is in an inadequate environment even if his blueprint genetic dictates that he should be tall (10).

According to WHO, stunting can be caused by direct factors, namely food intake, infection case records, and indirect factors such as food availability, household consumption regulation, inadequate care (psychosocial, hygiene, and sanitation), health facilities (health care facilities), and sanitation facilities. The main factors are not sufficient, and the socio-economic and cultural of the community are also important factors (10).

There is a relationship between nutritional deficiencies, infectious disease records, on child growth and development. The effects of consumption patterns, nutrition, and infection on nutritional status in children vary and are influenced by disease ecology, age, consumption patterns, and the type of food consumed. There are two possibilities to describe the relationship between the two: 1) poor nutritional conditions can result in impaired immunity and reduce resistance to infection; 2) exposure to infectious diseases that result in loss of appetite such as anorexia, malabsorption of nutrients, and an increase on energy metabolism, as well as other nutrients. Infectious diseases, especially (diarrhea and respiratory infections) that occur in children have a reciprocal relationship with the nutritional status of these children which has been proven in studies (11). Based on research conducted in Wonogiri Regency in 2018, it was stated that a history of infection with stunting had a significant relationship with a risk of 12 times greater (OR $=12 ; 95 \% \mathrm{Cl}=2.2-64.2)$ (12). Similar to the research conducted in Bengkulu Utara in 2019 which stated that there was a relationship between a history of infectious disease and the incidence of stunting with a risk of 15.21 times greater in children who had a history of infectious disease $(\mathrm{OR}=15.21 ; 95 \% \mathrm{Cl}=4.6-49.4)$ (13).
In overcoming the problem of stunting in toddlers, it is not enough just to optimize their nutritional intake. Environmental health factors such as latrine sanitation and the quality of family clean water sources must meet health requirements as well as the application of hygienic and sanitary parenting. It is important so that toddlers can avoid the risk of contracting infections which can inhibit the absorption of essential nutrients for growth, especially diarrheal diseases.

Diarrhea is an infectious disease that enters through the fecal-oral route due to the consumption of contaminated food or water, generally, E.coli is present. E.coli is a bacterium that is present in feces, if the handling of feces is not clean. It will pollute the environment, especially water, and will move to food if the children or the family do not behave in a hygienic manner or what can be called as unsanitary parenting, such as doing open defecation, consuming unclean water or polluted, not washing hands with soap, and littering so that it can become a nesting place for disease vectors.

Based on the results of the study, high levels of E.coli in dug wells owned by families were because most of the dug wells used were not equipped with protection and were at risk of contamination because the source of clean water in the form of dug wells was located close to the latrine with a distance of $<10$ meters. Beside that, the physical shape of the well that does not comply with the requirements will allow the water to be contaminated with pollution, especially biological pollution. Similar to research conducted in Surabaya in 2019 and South Sumatra in 2020, it is found that the source of drinking water consumed by the community has a relationship with cases of diarrhea in infants under five years old (1415).

This research is reinforced by a study conducted in the Bemung Lampung Health Center in 2019. It is stated that there is a relationship between the availability of clean water that does not meet the requirements of water quality with the incidence of diarrhea, and it can pose a risk of diarrhea in toddlers by 4.035 times greater compared to clean water users, which complies with the requirements (16).

Observations made found that many parents did not wash their hands with soap and did not teach their children about the importance of washing hands with soap at six important times and defecating in its place (not carelessly) where most parents dispose of baby's feces carelessly. A study in Libya reveals that aspects of the home environment is one of the factors that can increase the risk of stunting. The home environment includes poor home sanitation, insufficient water availability, and unsanitary environmental conditions. 
Inhibited growth and development of children are as a result of the incidence of infection experienced by the child (10). Based on research conducted in Gorontalo in 2019 , it was found that there was a relationship between environmental factors of access to clean water and the incidence of stunting with a risk of 3.07 times greater in children under five with poor access to clean water $(\mathrm{OR}=3.07 ; 95 \% \mathrm{Cl}=1.445-6.524)(17)$. Prevention of tropical enteropathy can be done by providing disposal facilities such as toilets, improvement of CTPS facilities, demonstrations of good hand washing practices, and improvement of water quality. Therefore, it can minimize the risk of stunted growth in children's height (10). Based on research conducted in Central Sulawesi in 2018, it is stated that environmental factors such as families who do not have latrines have a risk of stunting 7.398 times greater than families who have latrines $(\mathrm{OR}=7.398$; $95 \% \mathrm{Cl}=2,072-30,714)$. Washing hands has a risk of stunting that is 5.539 times greater than the behavior of washing hands $(\mathrm{OR}=5.359 ; 95 \% \mathrm{Cl}=1.758-16.341)$ (18). Based on research conducted in North Bengkulu in 2019 using a quantitative descriptive method with approach cross-sectional, taking a sample of 91 mothers who have toddlers by simple random sampling, it is stated that there is a relationship between environmental health and cases of stunting with a risk of 3.9 times greater on mothers who have poor environmental sanitation compared to mothers who have good environmental sanitation (13).

For stunting cases in children under 2 years old, it is estimated that 25 percent have a relationship with the incidence of diarrheal disease experienced by the child with more than 5 times greater (19). Similar to the research conducted in Kupang, East Nusa Tenggara in 2019, a sample of 200 respondents from a population of children aged 6-23 months showed that households with basic sanitation (providing clean water, defecation facilities, management of good waste, and household waste) can reduce the risk of stunting, and a good level of maternal hygiene including handwashing practices, food sanitation, nail hygiene, and the home environment can reduce the risk of stunting (20). Similar to a study conducted in the Way Urang Health Center, South Lampung in 2020 using a design case-control with a sample of toddlers aged 24-60 months, the results showed that there was a relationship between sanitation factors, personal hygiene, and a history of diarrhea with the incidence of stunting (21). Reinforced by research conducted in Surabaya in 2017 which showed that there is a relationship between hygiene practices and stunting and toddlers with poor hygiene practices are at risk of stunting greater than toddlers who are cared for with good hygiene by 4.808 times greater (22).

In West Pasaman Regency, the duration of diarrhea that occurs in toddlers in a matter of days is relatively high. Toddlers should not suffer from interference with the absorption of nutrients in their digestive system. It aims to optimize the growth of toddlers to achieve the maximum level of health in the future. Therefore, every toddler should not experience disturbances in the intestinal working system such as diarrheal disease in absorbing essential nutrients so that toddlers' growth can be optimal and it can prevent stunting.

The results of data analysis by applying GSEM analysis show that the duration of diarrhea in days has a path coefficient: $=-0.964$ which indicates that the duration of diarrhea directly has a direct and significant effect on the Z-score of TB/U or stunting in toddlers of $0.9642 \times 100 \%=92.9 \%$.

Diarrhea suffered by toddlers at one time generally ranges for 7 days. In this phase, the toddler's parents or caregivers will usually take the toddler to the first health facility, namely the primary health care. Later the primary health care will provide diarrhea medicine for toddlers. With the treatment process, the duration of diarrhea experienced by toddlers can be reduced to 3-4 days.

The study found that diarrheal disease in children in West Pasaman was $18.8 \%$. The result of this study is almost similar to the research conducted in the Kolono Health Center Work area, Southeast Sulawesi in 2019 by using a research design case-control with a sample size of 30 case samples and 30 control samples in toddlers aged 24-36 months. Stunting will have 5.537 times greater risk in children under five suffering from diarrheal infections $(\mathrm{OR}=5.537,95 \% \mathrm{Cl}=1.9-15.5)(23)$. In line with research conducted in Gorontalo in 2019, there is a relationship between diarrheal disease and stunting with a risk level of 3.28 times greater for children under five who often experience diarrheal disease $(\mathrm{OR}=3.28,95 \%$ $\mathrm{Cl}=1.542-6.973)$ (17). Based on research conducted in Kedung Rejo Village, Pakis District in 2020 with a sample of toddlers aged 24-35 months, it was found that toddlers experiencing diarrhea repeatedly were at risk of stunting 1.4 times greater than toddlers who rarely experienced diarrhea (24). Research conducted in Surabaya in 2017 stated that a history of diarrheal disease that was experienced repeatedly in the last 3 months increased the risk of stunting by 3.619 times greater in toddlers aged $2-<5$ years (22). Similarly, research conducted at Andalas Padang Timur in 2018 using an analytic study observational cross-sectional study design, taking a 
sample of 74 mothers of children $24-59$ months selected by simple random sampling showed that there is a relationship between a history of infectious disease with a mean ARI and diarrhea duration of illness $>3$ days per episode of illness with a risk level of 6.9 times greater (OR $=6.9,95 \% \mathrm{Cl}=2.1-22.7$ ) compared to children 24-59 months who had a mean duration of ARI and diarrhea $<3$ days per episodes of illness (25).

Continuous diarrhea can cause the intestines to not work optimally in absorbing essential nutrients for growth so it increases the risk of stunting in toddlers. Therefore, all efforts made to reduce the prevalence of stunting in the West Pasaman working area are optimizing efforts to improve the quality of sanitation facilities by keeping dug well buildings sanitary and closing dug wells that move less than 10 meters from family latrines so that water quality is maintained. A clean family can be free from contaminants of bacteria E.coli.

Excreta management can be done by onsite management which is management brought to a place or managed together at that place. In on-site management, excreta is collected and processed in septic tanks around the house. In outside management, excreta is drained or taken to a stool processing facility for further processing. As for joint management, the excreta management process is carried out on a group of communities collectively. Improving the quality of family latrine sanitation indirectly reduces the risk of stunting in children under five. Repairment and maintenance of latrine buildings and the effectiveness of their septic tanks in managing feces need to be improved. It aims to break the chain of contamination in the fecal-oral environment as well as an effort in preventive measures to prevent environmental enteropathy.

The application of hygienic and sanitary parenting patterns should be maximized by parents. Educating children to behave clean and healthy manner means training children to be able to protect themselves from the dangers of infectious diseases. Hygiene and sanitary behavior when preparing food to feed children, using clean water from protected sources, educating children not to defecate indiscriminately, and maintaining personal hygiene for themselves and their families can break the chain of fecal-oral contamination in the environment that can increase the risk of children being exposed to infectious diseases that allow children to experience stunting during their growth and development.

Pollution of water, soil, food contamination, and vector breeding can affect health caused by unsanitary disposal of feces. Environmental-based diseases that can occur due to the above conditions include diarrhea, cholera, dysentery, typhoid, paratyphoid, helminthiasis, and other digestive disorders caused by other parasites. The impact of this disease is that progress is hampered in social and economic aspects and becomes a burden on related parties based on morbidity, mortality, and life expectancy of children under five. Therefore, the disposal of human excreta or feces that meet the requirements is a very important aspect of environmental balance.

\section{CONCLUSION}

Knowing that parenting, food intake and environmental factors are indirect determinants which cause stunting under five, it is necessary to get special attention from the relevant agencies in preventing stunting in toddlers. The actions can include giving health consultations that are carried out regularly to monitor child growth and development, improving development and maintenance of sanitation facilities, as well as providing knowledge to the community on how to have a clean and healthy life to avoid all diseases. There should be formation of neighbors who care about neighbors in each neighborhood unit, especially in areas prone to stunting, by creating social gatherings for necessities. Government efforts need to promote the STBM stunting program and pre-marital counseling which discusses parenting, eating patterns, and a sanitary environment to keep families safe from disease.

\section{REFERENCES}

1. Chairunnisa E, Kusumastuti AC, Panunggal B. Revision of Inadequate Intake of Vitamin D, Calcium and Phosphorus in Stunting Children aged 12-24 Months Nutrition Science Study Program. J Nutr Coll. 2017. https://doi.org/10.14710/jnc.v7i1.20780

2. World Health Organization. Childhood Stunting: Challenges and Opportunities. Geneva: World Health Organization. 2013. http://apps.who.int/iris/bitstream/ handle/10665/107026/WHO_NMH_NHD_ GRS 14.1_eng.pdf? sequence $=1$

3. Ministry of Health of Republic Indonesia. Situasi Balita Pendek (Stunting) di Indonesia. Buletin Jendela Data dan Informasi Kesehatan. 2018;1(1):1-56. $\quad$ https://www.kemkes.go.id/ download.php?file $=$ download/pusdatin/buletin/ Buletin-Stunting-2018.pdf

4. World Health Organization. Reducing Stunting in Children: Equity Considerations for Achieving Global Nutrition Target 2025. Geneva: World Health Organization; 2018. https://apps.who.int/iris/handle/10665/260202

5. Apriluana G, Fikawati S. Analysis of Risk Factors for Stunting Incidence in Toddlers (0-59 Months) in Developing Countries and Southeast Asia. Med Penel Peng Kes. 2018;28(4):247-256. https://doi.org/10.22435/mpk.v28i4.472

6. Larasati NN. Factors Associated with Stunting 
Incidence in Toddlers Age 25-59 months at Posyandu in Wonosari II Health Center 2017. Thesis. Yogyakarta: Health Polytechnic of the Yogyakarta Ministry of Health; 2018.

7. Hafid F, Djabu U, Nasrul. The Effect of the SBABS Program on the Prevention of Stunting in Baduta Children in Banggai and Sigi Districts. Ind J Hum Nutr. 2017;(1):79-87. http://dx.doi.org/10.21776/ub.ijhn.2017.004.02.2

8. Fikawati S, Ahmad S, Vertamala A. Child and Adolescent Nutrition. Jakarta: PT Raja Grafindo Persada; 2017.

9. Province Health Office of West Sumatra. Profile of the West Sumatra Health Office 2017. Padang: Province Health Office of West Sumatra; 2017. www.dinkes.sumbarprov.go.id

10. Antonio, Weise S. WHA Global Nutrition Targets 2025 Stunting Policy Brief. Geneva: World Health Organization; 2012.

11. Kleinbaum DG, Klein M. Logistic Regression: A Self-Learning Text. Manhattan: Springer; 2010.

12. Pibriyanti K, Suryono S, Luthfi C. Factors Associated with Stunting Incidence in Toddlers in the Working Area of the Slogohimo Health Center, Wonogiri Regency. Darussalam Nutr J. 2019;3(2):42-49. http://dx.doi.org/10.21111/dnj.v3i2.3398

13. Wulandari, Fitri R, Darmawansyah. Relationship of Environmental Sanitation and History of Infectious Diseases with Stunting Incidence in the Work Area of the Kerkap Health Center, North Bengkulu Regency in 2019. Avicenna J IIm. 2019;14(2):6-13. https://doi.org/10.36085/avicenna.v14i02.374

14. Harsa IMS. The Relationship Between Clean Water Sources And The Incidence Of Diarrhea In Kampung Baru Resident At Ngagelrejo Wonokromo Surabaya. J Agromedicine Med Sci. 2019;5(3):124129. https://doi.org/10.19184/ams.v5i3.13813

15. Ofarimawan D, Ambarita LP. The Relationship of Drinking Water Sources with the Incidence of Diarrhea in South Sumatra Province. Spiracle. 2020;12(1):35-45 https://doi.org/10.22435/spirakel.v12i1.3130

16. Saputri N, Astuti YP. The Relationship between Environmental Factors and the Incidence of Diarrhea in Toddlers at the Bernung Health Center. JIKK. 2019;10(1):101-110. http://dx.doi.org/10.26751/jikk.v10i1.619
17. Ahmad ZF, Nurdin SSI. Environmental Factors and Behavior of Parents in Stunting Toddlers in Gorontalo Regency. J General Science and Health Aisyiyah. 2019;4(2):87-96. https://journal.polita.ac.id/index.php/jakiyah/article/ view/36

18. Nasrul N. Controlling the Stunting Risk Factors of Baduta Children in Central Sulawesi. JIKK. 2019;8(2):131-146. http://dx.doi.org/10.26751/jikk. v10i1.619

19. Ni'mah K, Nadhiroh SR. Factors Associated with Stunting Incidence in Toddlers. Med Gizi Indo. 2015;10(1):13-19. http://dx.doi.org/10.20473/mgi. v10i1.13-19

20. IIma NN, Salimo H, Pamungkasari EP. Prevalence and Determinants of Stunting among Children under Two Years of Age in Kupang, East Nusa Tenggara. J Mat Chil Heal. 2019;4(4):230-241. https://doi.org/10.26911/thejmch.2019.04.04.02

21. Sutarto S, Azqinar TC, Himayani R, Wardoyo W. The Relationship between Mother's Education Level and Family Income with Stunting Incidence in Toddlers in the Work Area of the South Lampung Health Center. J Dunia Kesmas. 2017;9(2):256653. https://doi.org/10.33024/jdk.v9i2.2380

22. Desyanti C, Nindya TS. The Relationship between Diarrhea History and Hygiene Practice with Stunting Incidence in Toddlers Age 24-59 Months in the Working Area of Simolawang Health Center, Surabaya. Amerta Nutr. 2017;1(3):243-251. http:// dx.doi.org/10.20473/amnt.v1i3.2017.243-251

23. Wahyuni N, Ihsan H, Mayangsari R. Risk Factors for Stunting Incidence in Toddlers Age 24 - 36 Months in the Work Area of the Kolono Health Center. J Masy Health. 2019;9(2):212-218. https://doi.org/10.31934/promotif.v9i2.973

24. Choiroh ZM, Windari EN, Proborini A. Hubungan antara Frekuensi dan Durasi Diare dengan Kejadian Stunting pada Balita Usia 24-36 Bulan di Desa Kedungrejo Kecamatan Pakis. JOIM. 2021;4(3):131-141. http://dx.doi.org/10.21776/ub.JOIM.2020.004.03.4

25. Setiawan E, Machmud R, Masrul. FaktorFaktor yang Berhubungan dengan Kejadian Stunting pada Anak Usia 24-59 Bulan di Wilayah Kerja Puskesmas Andalas Kecamatan Padang Timur Kota Padang Tahun 2018. $J$ Kesehatan Andalas. 2018;7(2):275-280. https://doi.org/10.25077/jka.v7i2.813 